\title{
A STUDY OF ESCHERICHIA COLI ISOLATED FROM CHRONIC URINARY INFECTION
}

\author{
K. A. BetTelheim* AND JoAn TAYlor \\ Salmonella Reference Laboratory, Colindale, London
}

ESCHERICHIA COLI is a common cause of both acute and chronic urinary infection. Most studies of serological types of $E$. coli responsible for urinary tract infection have been concerned with the acute disease and particularly with urinary tract infection in pregnancy (Kunin, 1963; Vosti et al., 1964); much less information is available about serotypes found in chronic disease.

We decided to make a study of the serological and biochemical types of strains of $E$. coli isolated from patients suffering from chronic infection of the urinary tract. All patients were admitted to a 28-bedded open general medical female ward over a period of $24 \mathrm{mth}$, and some were re-admitted on one or more occasions during the period of study. Many of them had received various forms of treatment, but none had been subjected to instrumentation. The study was part of a larger one on cross-infection in chronic urinary infections in patients in general medical wards, some of whom were suffering from other diseases (Spencer et al., 1968). Many of the patients were also infected with other organisms such as Proteus, Klebsiella, staphylococci and streptococci, but we confined our studies to $E$. coli.

\section{MATERIALS AND METHODS}

The diagnosis of urinary infection was made at St Bartholomew's Hospital (Spencer et al., 1968).

The organisms were isolated and subjected to a short set of tests at the hospital to determine that they belonged to the $E$. coli group. Strains were cultured and stored on nutrient agar, then sent to us in batches about every $6 \mathrm{mth}$; we tested them usually within a period of $4 \mathrm{wk}$. In some instances a strain was rechecked, in which case the original isolate might have been stored for some years. In a deliberate investigation of the effect of storage on a culture, some strains were retested after some years of storage and were found to give identical biochemical and serological reactions. As a rule one strain per specimen of urine was investigated; in a few cases up to four strains per specimen were tested and all were found to give identical biochemical and serological reactions, though some strains from specimens taken on different dates showed differences.

\section{Biochemical methods}

On examination in our laboratory each culture was plated on a blood and a MacConkey agar plate in order to see the colonial appearance. Single colonies were then subcultured to various media for carrying out the necessary tests. Strains showing the typical colonial appearance and the following reactions were accepted as $E$. coli: acid and usually gas in glucose and mannitol, no reaction in inositol, inulin, adonitol and cellobiose; $\mathrm{H}_{2} \mathrm{~S}$ was not

Received 7 Oct. 1968; accepted 25 Nov. 1968.

* Present address: Department of Biochemistry, Imperial College, London, S.W.7.

J. MED. MICROBIOL.-VOL. 2 (1969) 
produced, urease, phenylalanine and $\mathrm{KCN}$ tests were negative; malonate and Simmons citrate tests were negative; MR test positive, VP test negative, and gelatin not liquefied.

This definition of $E$. coli is given in the Report (1958) of the Enterobacteriaceae Subcommittee of the Nomenclature Committee of the International Association of Microbiological Societies. Some strains gave atypical reactions, which will be discussed in the section on biotyping.

Biotyping. The ability of each strain to ferment 16 carbohydrate substrates was tested: lactose, sucrose, salicin, dulcitol, inositol, adonitol, raffinose, sorbitol, arabinose, rhamnose, xylose, trehalose, glycerol, cellobiose, maltose and sorbose. The reactions were read at intervals up to $1 \mathrm{wk}$. It will be seen that inositol, adonitol, cellobiose and glycerol were used in biotyping in spite of the definition given above. It was found that a few strains failed to give typical reactions in one of these substrates, and one strain in two substrates. Nevertheless, typical reactions were obtained in all other tests and they belonged to known serotypes.

All strains were tested for their ability to decarboxylate three amino acids: ornithine, arginine and lysine.

\section{Serological methods}

Attempts were made to identify the somatic O-, surface $\mathrm{K}$ - and flagellar $\mathrm{H}$-antigens of each strain in order to classify each organism according to the internationally accepted serological classification described by Kauffmann (1944).

Preparation of diagnostic sera. Diagnostic antisera had been prepared against the known $E$. coli antigens; these comprised $147 \mathrm{O}$ somatic antigens and their $\mathrm{K}$ surface antigens together with $49 \mathrm{H}$ flagellar antigens. These sera were prepared in rabbits by Ewing's method (1956). Twelve pooled sera covering the $147 \mathrm{O}$-antigens and 6 pools covering the $49 \mathrm{H}$ antigens were prepared.

Preparation of antigens for agglutination tests. " $\mathrm{O}$ " (somatic antigen) suspensions were prepared by heating an overnight culture in $50 \mathrm{ml}$ of Oxoid nutrient broth in a boiling waterbath for half an hour. These suspensions had an approximate density of $3 \times 10^{8}$ organisms per $\mathrm{ml}$; they were preserved with $0.15 \mathrm{ml}$ commercial formalin and kept at room temperature.

" $\mathrm{K}$ " (surface antigen) suspensions were prepared by suspending the growth from an overnight culture on $\mathbf{0 . 0 5}$ per cent. glucose in Hartley digest agar in a solution of mercuric iodide in buffered formol-saline to an approximate density of $6 \times 10^{10}$ organisms per $\mathrm{ml}$.

" $H$ " (flagellar antigen) suspensions were prepared from cultures in which at least 80 per cent. of the organisms were motile. To obtain motile cultures it was necessary to subculture serially through Craigie tubes daily for a period up to $3 \mathrm{wk}$ and to incubate at $30^{\circ} \mathrm{C}$. When a strain rapidly traversed the Craigie tube it was subcultured in nutrient broth and incubated at $30^{\circ} \mathrm{C}$ for $4 \mathrm{hr}$; a hanging drop was examined to determine whether the culture was actively motile; if so it was diluted with physiological saline to give a concentration of $3 \times 10^{8}$ organisms per $\mathrm{ml}$. To this mixture commercial formalin was added to a concentration of 0.3 per cent. ( $\mathrm{v} / \mathrm{v})$. Strains in which no motility could be achieved after serial passage for 3 wk were considered to lack an " $\mathrm{H}$ " antigen and classed as $\mathrm{H}-$.

Serological examination of cultures. The somatic $(O)$ antigen of $E$. coli was identified in three steps. First, the antigen was tested with all 12 pooled sera; second, the antigen was tested with a single diagnostic dilution of each serum contained in the pools giving a positive reaction; third, each single serum giving a positive reaction was titrated against the antigen.

Equal volumes of $O$ suspension and the diluted sera were mixed in round-bottomed Dreyer tubes; a saline control was also prepared. These were incubated in a waterbath at $50^{\circ} \mathrm{C}$ overnight and read the following morning. Agglutination was considered to have occurred when there was a definite precipitate at the bottom of the tube, the supernatant solution was completely clear, and on tapping the agglutinated particles were visible. The control tubes appeared uniformly turbid after similar treatment. In some cases two or more $\mathrm{OK}$-antisera agglutinated a given $\mathrm{O}$ suspension to titre in which case the suspension was tested with adsorbed pure $\mathrm{O}$ antisera.

All OK-antisera that agglutinated the $O$ suspension to titre were used to carry out the $\mathrm{K}$ titrations. Doubling dilutions of sera were prepared in $0.5 \mathrm{ml}$ volumes in $2 \times \frac{1}{2}$ in. 
$(50 \times 12 \mathrm{~mm})$ round-bottomed tubes. To each tube of diluted serum and to a tube containing $0.5 \mathrm{ml}$ saline (control) two drops of $\mathrm{K}$ suspension were added with a 50 -dropper pipette. These tubes were incubated for $2 \mathrm{hr}$ at $37^{\circ} \mathrm{C}$ and left at room temperature overnight.

Agglutination was considered to have occurred if the supernatant fluid was clear and the deposit gave the appearance of a pellicle that covered the bottom of the tube and broke up on shaking into large clumps in a clear fluid. The control tube showed a small circular button-like deposit which formed a uniformly turbid suspension on shaking.

Equal volumes of $\mathrm{H}$ suspension and of each of the $\mathrm{H}$-antiserum pools were mixed in Dreyer tubes; a saline control was also prepared. These were incubated at $50^{\circ} \mathrm{C}$ for $2 \mathrm{hr}$. The formation of the typical fluffy flagellar type of agglutination in one or more of the pooled antisera and uniform turbidity in the saline control indicated specific agglutination in that pool.

Subsequently $\mathrm{H}$-antigen suspensions were tested in the separate $\mathrm{H}$-antisera that comprise each pool in which a positive reaction occurred. If an $\mathrm{H}$ suspension was agglutinated by only one $\mathbf{H}$-antiserum then it was considered to have been identified. In those few cases where agglutination occurred in more than one $\mathrm{H}$-antiserum, then titrations using doubling dilutions in physiological saline were used to ascertain by which $\mathrm{H}$-antiserum a given $\mathrm{H}$ suspension was agglutinated to titre.

\section{RESULTS}

In this study of 280 strains of Escherichia coli from urine of 85 patients the majority appeared smooth when grown on solid and fluid media, but some showed degradation changes of varying degree down to complete roughness.

\section{Biotype}

Each strain was tested on 16 carbohydrate substrates and the decarboxylase pattern noted. We state that in the identification tests for E. coli typical strains failed to ferment inositol, adonitol and cellobiose, but fermented glycerol. Of the 280 strains studied 2 fermented inositol, 21 fermented adonitol, 3 fermented cellobiose and 8 failed to ferment glycerol. These strains were accepted as $E$. coli as they gave one atypical reaction only, except for one strain that gave two. In all other respects the reactions were typical, and all the strains belonged to known $E$. coli serotypes. Although each strain was tested for its decarboxylase pattern it was found that the information obtained was valueless because the results were not always reproducible. It was shown once more that biotyping, the pattern of biochemical reactions, was valueless in the primary identification of a strain. For example, E. coli serotypes O1.K1.H12, O2.K1.H1, O2.K.H1, O2.K.H5, O2.K.H7, O2.K.H-, O4.K3.H5, O4.K.H5, O6.K.H1, O6.K13.H1, O7.K1.H6, O18ac.K77.H-, O25.K23.H1, O35.K.H5, O50.K.H1 and O134.K.H - all belonged to biotype A (table I).

Biotyping was of value in distinguishing strains within a known serotype. For example, between May 1962 and May 1964 eight patients were found to be infected with $E$. coli $\mathrm{O} 75 \mathrm{H}$ - (non-motile). Six of the strains had the Kantigen usually associated with $\mathrm{O} 75$, but a $\mathrm{K}$ designation has not been allotted in the international scheme; three strains lacked the K-antigen. From one patient $(\mathrm{Kn})$ one biotype (K) was isolated in May 1962 and another (D) in June, the first was $075 \mathrm{~K}$ absent, the second $075 \mathrm{~K}$ present. Table II shows the serotype and biotype. It will be noted that strains that were identical in their 
serological reactions, such as those from patients $\mathrm{Jo}, \mathrm{Di}, \mathrm{Eg}$ and $\mathrm{Si}$, were of the same biotype $\mathbf{J}$, but other strains of the same serotype from patients $\mathbf{M k}$, $\mathrm{Pr}$ and $\mathrm{Pu}$ were different biotypes- $-\mathrm{K}, \mathrm{L}$ and $\mathrm{D}$. These results suggest that

TABLE I

Fermentation reactions of biotypes of Escherichia coli

\begin{tabular}{|c|c|c|c|c|c|c|c|c|c|c|c|c|c|c|c|c|}
\hline \multirow[b]{2}{*}{ Biotype } & \multicolumn{16}{|c|}{ Fermentation of } \\
\hline & 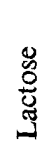 & 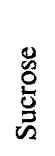 & $\frac{.5}{\frac{5}{\pi}}$ & $\frac{\overline{0}}{\frac{0}{3}}$ & $\begin{array}{l}\overline{0} \\
.00 \\
0 \\
\underline{0}\end{array}$ & $\begin{array}{l}\overrightarrow{0} \\
\stackrel{0}{0} \\
\stackrel{0}{0}\end{array}$ & 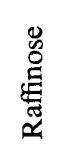 & 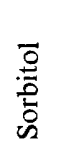 & 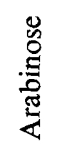 & 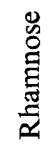 & $\frac{\ddot{\Delta}}{\grave{x}}$ & 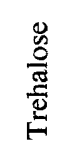 & 总 & 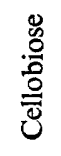 & $\begin{array}{l}\mathscr{0} \\
\text { : } \\
\text { : } \\
\text { \& }\end{array}$ & 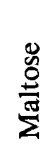 \\
\hline $\begin{array}{l}\text { A } \\
D \\
\text { E } \\
\mathbf{H} \\
\mathbf{J} \\
\mathbf{K} \\
\mathbf{L} \\
\mathbf{N} \\
\mathbf{O} \\
\mathbf{P}\end{array}$ & $\begin{array}{l}+ \\
+ \\
+ \\
+ \\
+ \\
+ \\
+ \\
+ \\
+ \\
+\end{array}$ & $\begin{array}{l}\overline{+} \\
+ \\
\pm \\
+ \\
+ \\
\pm \\
\pm \\
+\end{array}$ & $\begin{array}{l}+ \\
+ \\
+ \\
+ \\
+ \\
+ \\
+ \\
+\end{array}$ & $\begin{array}{l}+ \\
+ \\
+ \\
+ \\
+ \\
+ \\
+ \\
+\end{array}$ & $\begin{array}{l}\bar{z} \\
\bar{z} \\
\bar{z} \\
\bar{z} \\
\bar{z} \\
\bar{z}\end{array}$ & $\begin{array}{l}\overline{-} \\
\overline{-} \\
\overline{-} \\
\overline{-} \\
\overline{+} \\
\pm \\
\overline{-}\end{array}$ & $\begin{array}{l}\overline{+} \\
\pm \\
+ \\
+ \\
+ \\
+ \\
+ \\
- \\
-\end{array}$ & $\begin{array}{l}+ \\
+ \\
+ \\
+ \\
+ \\
+ \\
+ \\
+ \\
+ \\
+\end{array}$ & $\begin{array}{l}+ \\
+ \\
+ \\
+ \\
+ \\
+ \\
+ \\
+ \\
+ \\
+\end{array}$ & $\begin{array}{l}+ \\
+ \\
+ \\
+ \\
+ \\
+ \\
+ \\
+ \\
+ \\
+\end{array}$ & $\begin{array}{l}+ \\
+ \\
+ \\
+ \\
+ \\
+ \\
+ \\
+ \\
+ \\
+\end{array}$ & $\begin{array}{l}+ \\
+ \\
+ \\
+ \\
+ \\
+ \\
+ \\
+ \\
+ \\
+\end{array}$ & $\begin{array}{l}+ \\
+ \\
+ \\
+ \\
+ \\
+ \\
+ \\
+ \\
+ \\
+\end{array}$ & $\begin{array}{l}= \\
= \\
= \\
= \\
= \\
= \\
=\end{array}$ & $\begin{array}{l}+ \\
+ \\
+ \\
+ \\
+ \\
+ \\
+ \\
\pm \\
=\end{array}$ & $\begin{array}{l}+ \\
+ \\
+ \\
+ \\
+ \\
+ \\
+ \\
+ \\
+\end{array}$ \\
\hline
\end{tabular}

$+=$ Positive reaction; $--=$ negative reaction.

TABLE II

Biotypes of Escherichia coli 075

\begin{tabular}{|c|c|c|c|c|c|}
\hline \multirow{2}{*}{ Patient } & \multirow{2}{*}{ Ward } & \multirow{2}{*}{ Date } & \multicolumn{3}{|c|}{ E. coli isolated } \\
\hline & & & Sero & $\stackrel{p e}{H}$ & Biotype \\
\hline $\begin{array}{l}\mathrm{Kn} \\
\mathrm{Kn} \\
\mathrm{JO} \\
\mathrm{Di} \\
\mathrm{Eg} \\
\mathrm{Mk} \\
\mathrm{Pr} \\
\mathrm{Si} \\
\mathrm{Pu}\end{array}$ & $\begin{array}{l}G \\
G \\
G \\
G \\
G \\
G \\
G \\
G A \\
G\end{array}$ & $\begin{array}{r}\text { May } 1962 \\
\text { June } 1962 \\
\text { July } 1962 \\
\text { April-May } 1963 \\
\text { July } 1963 \\
\text { August } 1963 \\
\text { September } 1963 \\
\text { October } 1963 \\
\text { May } 1964\end{array}$ & $\begin{array}{l}75- \\
75- \\
75 \\
75- \\
75- \\
75- \\
75- \\
75- \\
75-\end{array}$ & $\begin{array}{l}= \\
= \\
= \\
= \\
= \\
=\end{array}$ & $\begin{array}{l}\text { K } \\
\text { D } \\
\text { J } \\
\text { J } \\
\text { J } \\
\text { K } \\
\text { L } \\
\text { J } \\
\text { D }\end{array}$ \\
\hline
\end{tabular}

cross-infection had not occurred between the patients with biotype $\mathrm{J}$ and those with biotypes $\mathrm{D}, \mathrm{K}$ and $\mathrm{L}$. Whether cross-infection occurred in patients infected with the same sero- and bio-type $\mathbf{J}$ it is not possible to say, as they were in the ward at different times and environmental studies were not made. The biotype designation by letter is devised for this study, but is not used internationally. A knowledge of the biotype was of value in subtyping within other known serotypes. 


\section{Serotype}

Table III lists the number of strains and the O-groups of the serotypes identified and the number of strains unidentified. When a single serotype was isolated from a patient on a number of occasions it was entered as one strain.

TABLE III

Escherichia coli $O$-groups in urine

\begin{tabular}{|c|c|c|c|}
\hline O-group & $\begin{array}{c}\text { Number of strains } \\
\text { isolated }\end{array}$ & O-group & $\begin{array}{c}\text { Number of strains } \\
\text { isolated }\end{array}$ \\
\hline $\begin{array}{l}1 \\
2 \\
3 \\
4 \\
6 \\
7 \\
8 \\
9 \\
11 \\
14 \\
16 \\
17 \\
18 \mathrm{ac} \\
21 \\
22 \\
23 \\
24 \\
25 \\
27 \\
28 \\
31 \\
35 \\
36 \\
37 \\
39 \\
40 \\
42 \\
44\end{array}$ & $\begin{array}{l}2 \\
8 \\
2 \\
3 \\
9 \\
7 \\
4 \\
2 \\
2 \\
1 \\
1 \\
3 \\
5 \\
1 \\
1 \\
1 \\
1 \\
3 \\
1 \\
1 \\
2 \\
2 \\
2 \\
1 \\
1 \\
3 \\
2 \\
1\end{array}$ & $\begin{array}{c}50 \\
54 \\
59 \\
60 \\
68 \\
69 \\
71 \\
75 \\
77 \\
78 \\
80 \\
81 \\
83 \\
84 \\
86 \\
87 \\
105 \mathrm{ac} \\
106 \\
108 \\
112 \mathrm{ab} \\
112 \mathrm{ac} \\
117 \\
120 \\
134 \\
141 \\
145 \\
\text { rough } \\
\text { unidentified }\end{array}$ & $\begin{array}{r}3 \\
1 \\
1 \\
1 \\
2 \\
4 \\
3 \\
8 \\
1 \\
1 \\
1 \\
1 \\
3 \\
1 \\
3 \\
1 \\
1 \\
2 \\
1 \\
2 \\
2 \\
2 \\
2 \\
2 \\
1 \\
3 \\
12 \\
23\end{array}$ \\
\hline 46 & 2 & Total & 162 \\
\hline
\end{tabular}

Repeated isolations from one patient of one serotype are listed once only.

It was found that strains in 50 O-groups were identified, but that O-groups 2 , $6,7,18 \mathrm{ac}$ and 75 were the most common, for they had been isolated from 5 or more patients in this series and had been identified, more commonly in repeated isolations from the same patient. Twelve of the 161 strains listed in table III were rough, and 23 could not be identified by any of the $147 \mathrm{O}$-antisera available; these latter strains may be representatives of new O-groups.

From many patients the strains isolated possessed a surface $\mathrm{K}$-antigen that could be typed; usually the K-type was that associated with the known O-group. For example from patient Ma the strain of O6.K13.H1 was isolated, K13 being the most common $\mathrm{K}$-antigen associated with $\mathrm{O6}$. In many strains, however, although a K-antigen was present it was unidentified. We would draw attention 
to the fact that many $\mathrm{K}$-antigens are accepted in the international scheme, but remain without numerals, and are therefore written as $\mathrm{K}$ ?.

The $\mathrm{H}$-antigen was identified in each motile strain and in no instance was the $\mathrm{H}$ of an unknown type. Table IV lists the full structure and the number of each type comprising the 280 strains studied.

\section{Serotype and biotype}

Most strains of the same O-group repeatedly isolated from one patient possessed the same flagellar antigen and belonged to the same biotype. For example, from the urine of patient Co E. coli O83.K ?.H31 biotype J was isolated on July 30th; the patient was treated with ampicillin until August 28th and sterile specimens were obtained on August 14th, and on September 2nd and 14th; then on September 20th and October 3rd E. coli O83.K ?.H31 was isolated; all three strains were biotype $J$. These results suggest either that the patient relapsed or that re-infection occurred with the same organism. Twelve further cases showed a similar picture, as from each individual the same sero- and bio-type was isolated on a number of occasions. Among these 13 patients were six from whom on one occasion a different sero- and bio-type was isolated suggesting that the main infection was due to one sero- and bio-type. These single isolations were not considered to be examples of re-infection, as they were usually preceded and succeeded by the main infecting sero- and bio-type; moreover, very rarely was more than one colony examined per specimen of urine.

Strains of one serotype that were isolated from different patients who were not in the ward at the same time and were unconnected in any way, were of different biotypes. For example, patients To and $\mathrm{Pa}$ were infected with $E$. coli O69.K ?.H6 of the same biotype J, which suggested that cross-infection had occurred. Patient $\mathrm{Ru}$ admitted $13 \mathrm{mth}$ after patients To and $\mathrm{Pa}$ was also infected with the same serotype but biotype $\mathrm{H}$, which differs from $\mathbf{J}$ in its failure to ferment sucrose; these differences indicated a different biotype and that cross-infection had not occurred. The use of typing in cross-infection in this study is reported by Spencer et al. (1968).

Patient $\mathrm{Bi}$ is an example of re-infection with different sero- and bio-types of $E$. coli. During a 2-wk period serotype O42.K ?.H37 biotype N, O60.K ?.Hbiotype $\mathbf{J}$ and O7.K ?.H - biotype D were isolated on different occasions.

\section{Antigenic variation}

From a number of patients whose urine was tested repeatedly over a period of time, the strains of $E$. coli isolated were smooth, rough, motile or non-motile in the various specimens; in a few instances two serotypes were isolated from a single specimen. Some strains had the classical K-antigen usually associated with the known O-group, but in others the classical $\mathrm{K}$-antigen was absent and a different $\mathrm{K}$-antigen was present. During the course of infection in a single patient both types of strain might occur from time to time, those possessing and 
E. COLI FROM CHRONIC URINARY INFECTIONS

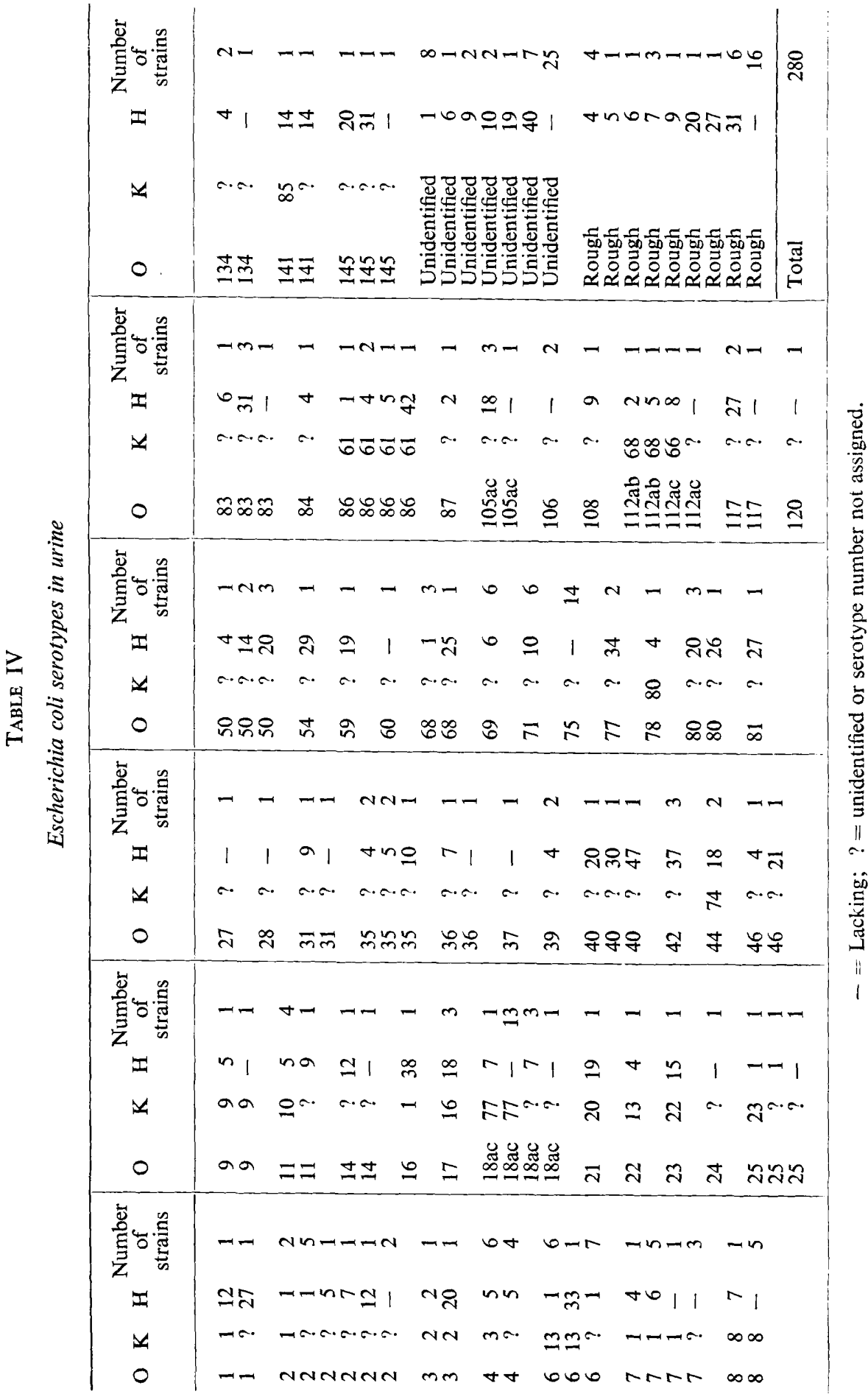


those lacking the K-antigen. Untreated suspensions of strains lacking the $\mathrm{K}$-antigen were agglutinated by the appropriate $\mathrm{O}$-antiserum, whereas strains possessing the $\mathrm{K}$-antigen were unaffected.

$O$ variation. Many strains of $E$. coli repeatedly isolated from the same patient, though found to be of the same serotype, showed antigenic change. These changes were detected as the result of testing each $O$ suspension against all $147 \mathrm{O}$-antisera and titrating all sera giving agglutination. An example of change from smooth to rough is patient Wa from whose urine on each of three occasions two $E$. coli serotypes were isolated. On the first occasion they were identified as O50.K ?.H20 biotype $\mathrm{N}$ and O4.K ?.H5 biotype A. On the second occasion one strain was identified as O50.K ?.H20 biotype $\mathrm{N}$ whereas the second was $\mathrm{O}$ rough $\mathrm{H} 5$ biotype $\mathrm{A}$. On the third occasion two strains were isolated, one O50.K ?.H20 biotype $\mathrm{N}$ and the second $\mathrm{O}$ rough $\mathrm{H} 20$ biotype $\mathrm{N}$. The two rough strains showed a minor change in colonial appearance in that they were slightly more translucent, but did not show the matt appearance and crenated edge; both were clumped in normal saline.

Another type of variation encountered was the gradual loss of agglutinability of the strain in the diagnostic serum. From patient Hu E. coli O71.K?.H10 biotype $O$ was isolated; this strain was agglutinated to 1600 (homologous titre). Four months later the same sero- and bio-type was isolated, but the organism was agglutinated to 800 only; after a further period of $3 \mathrm{wk}$ the isolate of the same sero- and bio-type was agglutinated to 400 only. These results were confirmed by testing all strains in an absorbed pure 071 serum; the same loss of agglutinability was observed.

The last type of variation is that in which agglutination occurred in one diagnostic antiserum, but later isolates were agglutinated non-specifically in additional antisera. As an example, the first strain of $E$. coli O6.K13.H1 isolated from patient $\mathrm{Ma}$ was not agglutinated by any other serum; the strain isolated $2 \mathrm{mth}$ later was agglutinated in lower dilution by $\mathrm{O} 6$ serum and was also agglutinated by $\mathrm{O} 138$ serum in very high concentration; the strains isolated 8 and $9 \mathrm{mth}$ later were still agglutinated by $\mathrm{O} 6$ and 0138 serum. The last strain tested, which was isolated after $11 \mathrm{mth}$, was still agglutinated by $\mathrm{O} 6$ and 0138 antiserum, but in addition it was agglutinated to titre by crude but not by pure $\mathrm{O} 4$ antiserum. Serotype $\mathrm{O} 4$ is a complex in which some of the basic antigens present are found in other O-groups. The changes described here are typical of an organism that is gradually being degraded, so allowing for agglutination to occur with antigens that become reactive as the result of the process of degradation. These baser antigens are common to many $E$. coli serotypes. All strains of $E$. coli $\mathrm{O6}$ isolated from this patient were biotype A.

$K$ variation. The only change in surface antigens we encountered was a loss variation. Patient Ma was infected with E. coli O6.K13.H1; over the following months strains of the same O-type were isolated, but the titre in the diagnostic $\mathrm{K}$-antiserum fell from 800 given by isolates early in the disease to less than 50 by those isolated late.

$H$ variation. The change encountered was a loss or gain of $\mathrm{H}$-antigen, the $\mathrm{O}$ and $\mathrm{K}$ remaining constant. From patient To from one sample of urine 
E. coli O14.K ?.H12 and O14.K?.H - were isolated, whereas from patient $\mathrm{St}$ the first strain isolated was O105ac.K?.H-; $1 \mathrm{mth}$ later and in subsequent specimens of urine O105ac.K ?.H18 was isolated. All strains were biotype P.

Complex variation affecting sero- and bio-type. Rarely were repeated isolates from a single patient found to change in one antigen only; usually changes affecting all three antigens were noted during the period of study.

Patient Lo was infected with Proteus, Klebsiella, E. coli of different types on three occasions and E. coli O18ac on 9 occasions (table V). Some of the strains of O18ac possessed K77 and H7 whilst others lacked K77 or H7 or both. Six of these strains were biotype E, fermenting dulcitol, three failed to do so and

TABLE V

Biotype and serotype variation of $E$. coli O18ac strains from patient Lo

\begin{tabular}{|c|c|c|c|c|}
\hline \multirow{2}{*}{$\begin{array}{l}\text { Date of } \\
\text { isolation }\end{array}$} & \multirow{2}{*}{$\begin{array}{l}\text { Antigenic } \\
\text { structure }\end{array}$} & \multirow{2}{*}{ Biotype } & \multicolumn{2}{|c|}{ Agglutination titre with } \\
\hline & & & O18ac serum & O17 serum \\
\hline $\begin{array}{l}7 \text { May } 1962 \\
6 \text { June } 1962 \\
7 \text { July } 1962\end{array}$ & $\begin{array}{l}\text { O18ac.K77.H-- } \\
\text { O18ac.K77.H-- } \\
\text { O18ac.K?.H7 }\end{array}$ & $\begin{array}{l}\text { atypical } E^{*} \\
\text { atypical } E^{*} \\
E\end{array}$ & $\begin{array}{l}1600 \\
3200 \\
1600\end{array}$ & $\begin{array}{l}400 \\
800 \\
800\end{array}$ \\
\hline 15 July 1962 & O18ac.K $77 . H-$ & atypical $\mathrm{E}^{*}$ & 1600 & 1600 \\
\hline 26 Julv 1962 & O18ac.K $77 . H-$ & $\mathrm{E}$ & 3200 & 3200 \\
\hline 26 July 1962 & O18ac.K?.H7 & $\mathrm{E}$ & 1600 & 800 \\
\hline $\begin{array}{r}7 \text { Aug. } 1962 \\
17 \text { Aug. } 1962\end{array}$ & $\begin{array}{l}\text { O18ac.K?.H- } \\
\text { O18ac.K?.H7 }\end{array}$ & $\stackrel{E}{E}$ & $\begin{array}{l}1600 \\
1600\end{array}$ & $\begin{array}{l}800 \\
800\end{array}$ \\
\hline
\end{tabular}

* Dulcitol-negative.

the results were independent of the changes in antigenic structure. The nondulcitol-fermenting strains were not considered to be a different biotype, because it is known that a change in fermentation pattern may occur in the degradation process and in any case the $\mathrm{O}$-antigen of all strains was identical. Also from a single specimen of urine O18ac.K77.H- biotype $E$ and O18ac.K77.H - biotype atypical (non-dulcitol-fermenting) strains were isolated, whereas from another specimen O18ac.K77.H - and O18ac.K?.H7, both biotype $\mathrm{E}$, were isolated. The strains of O18ac showed the known crossreaction with $\mathrm{O} 18 \mathrm{ab}$ and $\mathrm{O} 4$ antisera, but also reacted with $\mathrm{O} 17$ antiserum; this last reaction was quite minor in the strains isolated early in the infection, but increased to a maximum after $2 \frac{1}{2} \mathrm{mth}$ from the first isolation and then decreased during the subsequent month of the disease. All strains reacted with pure $\mathrm{O} 18 \mathrm{c}$ antiserum but not with pure $\mathrm{O} 17$, pure $\mathrm{O} 4$ or pure $\mathrm{O} 18 \mathrm{~b}$ antiserum, so that there was no doubt as to their identity.

Patient No is an example in which the first isolate was identified as O83.K ?.H - biotype J. Subsequently on six occasions a rough motile H31 biotype-J strain was isolated and on nine other occasions non-motile rough strains of biotype J. From this patient's faeces a smooth E. coli O83.K?.H31 biotype $\mathbf{J}$ was isolated. Some of these rough strains failed to produce gas in 
some or all the sugars tested. This failure to produce gas is known to occur in degraded strains. The strain isolated from faeces was regarded as having the complete antigenic structure.

From patient St E. coli $\mathrm{O} 35$ having the typical K-antigen associated with this $\mathrm{O}$ and $\mathrm{H} 4$, biotype $\mathrm{J}$, was isolated; a month later, and subsequently, O35.K-.H5 biotype A was isolated. The first isolate was agglutinated by $\mathrm{O} 35$ antiserum only, whereas the later isolates were agglutinated in low dilution by other sera. The possibility of relapse or a new infection will be discussed.

Another patient $\mathrm{Ch}$ was infected with $E$. coli $\mathrm{O} 2 . \mathrm{K} 1 . \mathrm{H} 1$ and $\mathrm{O} 2 . \mathrm{H} 1$, both biotype A, which were both isolated on two occasions; these were considered to be the same type. A week later E. coli O25.K23.H1 biotype A was isolated

TABLE VI

Serotype changes in E. coli isolated from single patients on three or more occasions

\begin{tabular}{l|c}
\hline \multicolumn{1}{c|}{ Serotype change in $E$. coli isolates } & $\begin{array}{c}\text { Number (and percentage) } \\
\text { of patients showing this } \\
\text { serotype change }\end{array}$ \\
\hline $\begin{array}{l}\text { None . Degradation changes in original serotype } \\
\text { Re-infection with different serotypes }\end{array}$ & $\begin{array}{r}13(34 \cdot 2) \\
7(18 \cdot 4) \\
18(47 \cdot 4)\end{array}$ \\
\hline Total patients & 38 \\
\hline
\end{tabular}

and subsequently $\mathrm{O}$ ?.K ?.H1 biotype A. The interpretation of these resultswhether they are the result of variation in antigenic structure or biotype or whether they are new infections-will be discussed.

Table VI summarises the findings in 38 of the 85 patients from each of whom three or more strains of $E$. coli were isolated at different times during the course of infection. It will be seen that 13 patients were infected with one serotype, which was isolated on three or more occasions. From nine patients degraded strains were isolated which, because of their serological and biochemical reactions, were believed to be the same type as the original isolates. Sixteen were infected with different $E$. coli serotypes at different times.

In 36 of these 38 patients a mixture of organisms was found on at least one occasion. The mixture contained $E$. coli, sometimes with proteus, staphylococci, streptococci or other organisms.

\section{Discussion}

Biotyping of $E$. coli was of little value alone, for we found that a given set of reactions was obtained from a number of different serotypes; it was necessary to know both the serotype and the biotype of each strain studied in order to assess its significance both in repeated isolations from a single patient and in cross-infection from one patient to another.

Antigenic variation is not uncommon among the Enterobacteriaceae 
(Wilson and Miles, 1964). The more usual changes are degrees of loss variation which may affect the somatic O-, surface $\mathrm{K}$ - and flagellar $\mathrm{H}$-antigens. In the gross change from the smooth to rough colonial form the diagnostic somatic and surface antigens are lost even though the $\mathrm{H}$-antigen may occasionally remain. Growing an organism in a depleted medium or one containing antibodies or an inhibitory substance may cause such a change, and there are probably many other unknown factors that may do so. In urinary infection the patient is treated with various inhibitory substances, which are excreted in the urine. Moreover, some patients have been shown to excrete antibodies to their infecting organisms (Vosti and Remington, 1968). Ejther or both these factors as well as other factors unknown may affect the antigenic structure of the infecting strain and so lead to degradation. In the present study a knowledge of the serotype and the biotype of strains repeatedly isolated from a single patient made it possible to decide whether infection was due to a different organism or to degraded derivatives of the original type. It would have been impossible to make such an interpretation with any accuracy unless both methods of typing had been carried out. Obviously some organisms in the process of degradation lost the ability to ferment a sugar or, though retaining this property, produced acid only, although the original strain had produced acid and gas. It is difficult to fit such strains into the picture of infection even though one has a knowledge of the antigenic structure. From patient St E. coli O35.K ?.H4 biotype $\mathrm{J}$ and O35.K ?.H5 biotype A were isolated; as these strains differed both in their $\mathrm{H}$-antigens and in their biotypes, one must regard this patient as having been infected by two different organisms. Patient $\mathrm{Ch}$ was infected by $E$. coli $\mathrm{O} 2 . \mathrm{K} 1 . \mathrm{H} 1$ and $\mathrm{O} 2 . \mathrm{H} 1$ both biotype A; subsequently she was infected by O25.K23.H1 biotype $\mathrm{A}$ and O?.K ?.H1 biotype A. This last strain of unknown $\mathrm{O}$ - and $\mathrm{K}$-type might be regarded as a degraded variety of either the $\mathrm{O} 2$ or the $\mathrm{O} 25$ type because the $\mathrm{H}$-antigens and the biotype were the same. On the other hand, it could be regarded as a new infection due to an organism with a different OK structure. This strain did not show any colonial or serological changes associated with degradation. We regarded this as reinfection with different serotypes.

It has been shown that the somatic antigenic determinants of most Enterobacteriaceae, including $E$. coli, consist of specific arrangements of sugar components within the lipopolysaccharide molecule of the cell wall structure (Ørskov et al., 1967). The sugars known to be concerned in these determinants include rhamnose, glucose, galactose, mannose, as well as derivatives of these sugars. This might be the explanation for the relation of the degradation in fermentation pattern to antigenic structure, since similar systems have been shown to be involved in these changes (Utter, 1958; Nikaido et al., 1964).

Degradation as indicated by changes in fermentative reactions was uncommon. The broadening of the agglutination pattern that was seen in some chronic urinary infections might give useful information, for if such a strain were isolated from the first sample of urine of a new patient, it might suggest that previous episodes of infection had occurred. The question of the interpretation of infection with degraded and rough strains of $E$. coli needs further 
study to determine their significance. A knowledge of the serotype and biotype was valuable in the interpretation of findings in a patient and in studying cross-infection.

\section{SUMMARY}

Two hundred and eighty strains of Escherichia coli isolated from 85 female patients with chronic urinary tract infections in one hospital were tested for their serological and biochemical reactions.

Biochemical and serological variations and degradation changes were observed in strains isolated repeatedly during the course of the disease in separate patients; their significance is discussed.

From 34.2 per cent. of 38 patients the same sero- and bio-type of $E$. coli was repeatedly isolated, from 18.4 per cent. degraded strains probably the same as the original infecting type were isolated, and in 47.4 per cent. the seroand bio-type changed during the course of the disease.

\section{REFERENCES}

EWING, W. H.

1956. Publ. Hlth Lab., 14, 138.

INTERNATIONAL ASSOCIATION OF MICRO1958. Int. Bull. Bact. Nomencl., 8, 25.

BIOLOGICAL SOCIETIES: ENTEROBACTERIACEAE SUBCOMMITTEE OF THE NOMENCLATURAL COMMITTEE

KAUFFMANN, F. .

1944. Acta path. microbiol. scand., 21, 46.

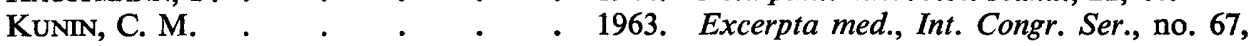

Nikaido, H., Nikamo, K., Subbaiah, 1964. Nature, Lond., 201, 1301.

T. V., AND StOcker, B. A. D.

ØRSKov, F., ØRSKOV, I., JANN, B., JANN, 1967. Acta path. microbiol. scand., 71, 339.

K., MÜller-SetTZ, E., AND WeStPhal, O.

SPENCER, A. G., Mulcahy, P. D., 1968. Lancet, 2, 839.

Shooter, R. A., O'Grady, F. W., BetTELHEIM, K. A., AND TAYLOR, JoAN UTTER, M. F.

Vosti, K. L., Goldberg, L. M., Monto, A. S., AND RANTZ, L. A.

Vosti, K. L., AND Remington, J. S. WILSON, G. S., AND MiLES, A. A. .

1958. A. Rev. Biochem., 27, 245.

1964. J. Clin. Invest., 43, 2377.

1968. J. Lab. Clin. Med., 72, 71.

1964. Topley and Wilson's Principles of bacteriology and immunity, 5th ed., London, vol. 1, p. 387. 